\title{
Determinan Ketepatan Waktu Pelaporan Keuangan pada Organisasi Perangkat Daerah dengan Sistem Pengendalian Intern sebagai Pemoderasi
}

\author{
Baiq Muslihan Hidni ${ }^{1}$ \\ Fakultas Ekonomi dan Bisnis \\ Universitas Mataram, Indonesia
}

\author{
Budi Santoso ${ }^{2}$ \\ Fakultas Ekonomi dan Bisnis \\ Universitas Mataram, Indonesia
}

\author{
Endar Pituringsih ${ }^{3}$ \\ Fakultas Ekonomi dan Bisnis \\ Universitas Mataram, Indonesia \\ Surel : baiqhidny@gmail.com
}

ABSTRAK

\begin{abstract}
Penelitian bertujuan menganalisis pengaruh komitmen organisasi, gaya kepemimpinan dan SAKD terhadap ketepatan waktu pelaporan keuangan dengan sistem pengendalian intern sebagai variabel pemoderasi. Populasi penelitian adalah pegawai bagian akuntansi pada 38 OPD Provinsi Nusa Tenggara Barat. Hasil penelitian menunjukkan bahwa komitmen organisasi berpengaruh positif dan signifikan terhadap ketepatan waktu pelaporan keuangan. Gaya kepemimpinan dan SAKD berpengaruh positif dan tidak signifikan terhadap ketepatan waktu pelaporan keuangan. Sedangkan sistem pengendalian intern tidak mampu memperkuat pengaruh komitmen organisasi, gaya kepemimpinan, dan SAKD terhadap ketepatan waktu pelaporan keuangan.
\end{abstract}

Kata Kunci: Ketepatan Waktu Pelaporan Keuangan, Komitmen Organisasi; Gaya Kepemimpinan; SAKD; Sistem Pengendalian Intern.

\section{Determinants of Timeliness of Financial Reporting in Regional Apparatus Organizations With Internal Control Systems as Moderators}

\begin{abstract}
This study aims to analyze the effect of organizational commitment, leadership style and SAKD on the timeliness of financial reporting with the internal control system as a moderating variable. The research population is the accounting staff at 38 OPDs of West Nusa Tenggara Province. The results show that organizational commitment has a positive and significant effect on the timeliness of financial reporting. Leadership style and SAKD have a positive and insignificant effect on the timeliness of financial reporting. While the internal control system is not able to strengthen the influence of organizational commitment, leadership style, and SAKD on the timeliness of financial reporting.
\end{abstract}

Keywords: $\quad$ Timeliness of Financial Reporting; Organizational Commitment; Leadership Style; SAKD; Internal Control System.

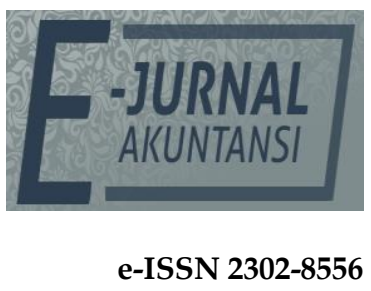

Vol. 31 No. 11

Denpasar, November 2021

Hal. 2895-2911

DOI:

10,24843/EJA.2021.v31.i11.p17

PENGUTIPAN:

Hidni, B. M., Santoso, B., \& Pituringsih, E. (2021). Determinan

Ketepatan Waktu Pelaporan Keuangan pada Organisasi Perangkat Daerah dengan Sistem Pengendalian Intern sebagai Pemoderasi. E-Jurnal Akuntansi, 31(11), 2895-2911

\section{RIWAYAT ARTIKEL:}

Artikel Masuk:

10 September 2021

Artikel Diterima:

28 November 2021

Artikel dapat diakses : https://ojs.unud.ac.id/index.php/Akuntansi/index 


\section{PENDAHULUAN}

Peraturan Pemerintah Tahun 2010 Nomor. 71 mengenai Sistem Akuntansi Pemerintahan mengharuskan mutu laporan keuangan wajib relevan, andal, bisa diperbandingkan, serta bisa dimengerti. Bila data yang tercantum dalam informasi finansial bisa pengaruhi ketetapan konsumen dengan membantu konsumen menilai kejadian masa lalu ataupun saat ini, memperhitungkan masa depan, serta mengkonfirmasi ataupun membetulkan hasil penilaian masa lalunya, hingga informasi finansial bisa dibilang relevan (Eristanti et al., 2019). Buat menggapai relevansi itu, informasi finansial wajib di informasikan tepat waktu (timeliness). Ketepatan waktu itu sendiri tidak menjamin relevansi, namun tanpa ketepatan waktu tidak terdapat relevansi. Ketepatan waktu ialah batasan penting pada publikasi laporan keuangan.

Nusa Tenggara Barat merupakan salah satu provinsi yang ada di Indonesia yang membuat laporan pertanggungjawaban berupa Laporan Keuangan Pemerintah Daerah (LKPD), LKPD Provinsi Nusa Tenggara Barat memperoleh opini wajar tanpa pengecualian (WTP) oleh Badan Pemeriksa Keuangan (BPK). Meskipun mendapatkan WTP sejak 2011-2019, tetapi Badan Pemeriksa Keuangan (BPK) masih menemukan adanya kelemahan sistem dan prosedur pengendalian intern dalam penyusunan laporan keuangan tentang Pengelolaan kas pada Pemprov NTB belum tertib. BPK juga menemukan adanya ketidakpatuhan terhadap peraturan perundang-undangan dalam pengelolaan keuangan daerah antara lain pembayaran belanja pegawai tidak sesuai dengan ketentuan senilai Rp167.652.445,- dan belanja perjalanan dinas pada sekretariat DPRD tidak sesuai ketentuan senilai Rp629.810,529,- dan pelaksanaan 13 paket pekerjaan pada lima OPD tidak sesuai kontrak senilai Rp1.868.661.919,69 diantaranya kekurangan volume pekerjaan, keterlambatan penyelesaian pekerjaan belum dikenakan denda, dan pelaksanaan pekerjaan yang tidak sesuai spesifikasi kontrak.

Penelitian yang dilakukan oleh Fransiska et al., (2015) yang menghasilkan komitmen organisasi berpengaruh terhadap Keandalan Pelaporan Keuangan Pemerintah Daerah, Mutiana et al., (2017) dan Agung \& Gayatri (2018)dengan hasil komitmen organisasi secara simultan berpengaruh terhadap kualitas laporan keuangan Pemerintah Daerah. Eristanti et al., (2019) menghasilkan komitmen organisasi berpengaruh positif terhadap ketepatan waktu pelaporan keuangan. Sedangkan Amalia (2014) mendapatkan hasil komitmen organisasi tidak mempengaruhi ketepatan waktu, Rachmawati (2014) dengan hasil komitmen organisasi berpengaruh tidak signifikan terhadap keterandalan dan ketepatwaktuan pelaporan keuangan daerah.

Belum terdapat riset yang spesifik terkait gaya kepemimpinan terhadap ketepatan waktu pelaporan keuangan. Riset yang dilakukan oleh Nurillah \& Muid (2014) serta Suarmika et al., (2016) gaya kepemimimpinan berpengaruh positif terhadap penerapan anggaran berbasis kinerja, Andriyani et al., (2016) menghasilakan gaya kepemimpinan berpengaruh signifikan terhadap penerapan transaparansi pelaporan keuangan. Pradipa (2016) dan Agung \& Gayatri (2018) dengan hasil gaya kepemimpinan berpengaruh positif dan signifikan terhadap kualitas laporan keuangan Pemerintah Daerah. Afifah (2019) menghasilkan gaya kepemimpinan tidak berpengaruh terhadap kualitas laporan keuangan pemerintah daerah. 
Riset mengenai sistem akuntansi keuangan daerah masih sedikit yang meneliti terhadap ketepatan waktu hanya saja penelitian sebelumnya dominan terhadap kualitas laporan keuangan. Penelitian yang dilakukan oleh Drama (2014) dan Murapi (2016) SAKD berpengaruh signifikan positif terhadap kualitas laporan keuangan, dan Eristanti et al., (2019) dengan hasil sistem akuntansi keuangan daerah berpengaruh positif terhadap ketepatan waktu pelaporan keuangan. Sedangkan Latifah (2015) mendapatkan hasil SAKD tidak berpengaruh terhadap kualitas laporan keuangan.

Riset yang terkait dengan sistem pengendalian intern terhadap ketepatan waktu, yaitu Rachmawati (2014) dan Astrawan et al., (2016) mendapatkan hasil penelitian sistem pengendalian intern berpengaruh signifikan positif terhadap ketepatan waktu. Eristanti et al., (2019) menghasilkan sistem pengendalian intern memperlemah pengaruh komitmen organisasi terhadap ketepatan waktu. Sistem pengendalian intern memperkuat pengaruh SAKD terhadap ketepatan waktu. Penelitian Amalia (2014), Mutiana et al., (2017) dan Miharja et al., (2020) Pengendalian Intern Akuntansi tidak berpengaruh terhadap ketepatan waktu pelaporan keuangan.

Penelitian yang membahas tentang komitmen organisasi dan sistem akuntansi keuangan daerah terhadap ketepatan waktu pelaporan keuangan pada Organisasi Perangkat Daerah sudah banyak dilakukan, namun belum ada penelitian terdahulu yang menggunakan variabel gaya kepemimpinan terhadap ketepatanwkatu pelaporan keuangan secara spesifik. Selain itu, masih terdapat ketidakkonsitenan hasil penelitian atas faktor-faktor yang mempengaruhi ketepatan waktu pelaporan keuangan sehingga peneliti merasa perlu meguji ulang variabel ini kembali dengan menambahkan variabel gaya kepemimpinan dengan lokasi, jumlah sampel, dan periode waktu yang berbeda.

Rumusan masalah dari penelitian ini adalah apakah komitmen organisasi, gaya kepemimpinan dan sistem akuntansi keuangan daerah berpengaruh terhadap ketepatan waktu pelaporan keuangan, apakah sistem pengendalian intern memoderasi pengaruh komitmen organisasi, gaya kepemimpinan dan sistem akuntansi keuangan daerah berpengaruh terhadap ketepatan waktu pelaporan keuangan. Selaras dengan rumusan maka tujuan dari penelitian ini adalah untuk menganalisis pengaruh komitmen organisasi, gaya kepemimpinan dan sistem akuntansi keuangan daerah terhadap ketepatan waktu pelaporan keuangan dan untuk menganalisis sistem pengendalian intern dalam memoderasi pengaruh komitmen organisasi, gaya kepemimpinan dan sistem akuntansi keuangan daerah terhadap ketepatan waktu pelaporan keuangan.

Penelitian ini menggunakan teori penatalayanan (stewardship theory) dan teori kepatuhan (compliance theory). Teori Stewardship dikemukakan oleh Donaldson \& Davis (1991) menggambarkan situasi dimana para manajemen tidaklah termotivasi oleh tujuan-tujuan individu tetapi lebih ditujukan pada sasaran hasil utama mereka untuk kepentingan organisasi. Teori tersebut mengasumsikan bahwa adanya hubungan yang kuat antara kepuasan dan kesuksesan organisasi. Dalam hal ini pemerintah sebagai pemegang amanah (steward) fokus terhadap kepentingan masyarakatnya dan dituntut untuk mempertanggung jawabkan kegiatannya kepada masyarakat sebagai pihak pemberi amanah (principal). Untuk mempertanggungjawabkan kepada 
masyarakat, pemerintah membuat laporan keuangan. Komitmen organisasi dari pihak-pihak terkait akan mewujudkan laporan keuangan yang bermanfaat bagi pengguna. Laporan keuangan dapat bermanfaat kepada penggunanya ketika laporan tersebut tepat waktu, sehingga ketepatan waktu sangat berpengaruh dalam pelaporan keuangan.

Bagi Rosalin \& Kawedar (2011), pengertian teori kepatuhan mengacu pada SAP (Standar Akuntansi Pemerintah), yaitu standar yang harus dipatuhi pemerintah dalam menerapkan sistem serta prosedur pelaporan akuntansi. Adanya standar dan sistem yang diterapkan harus didukung oleh Sistem Pengendalian Internal. Menerapkan Sistem Pengendalian Internal alhasil laporan keuangan pemerintah menghasilkan informasi yang berguna bagi user. Kebermanfaatan informasi disini terkait dengan relevannya informasi dalam laporan keuangan dimana salah satunya terkait dengan ketepatan waktu, karena laporan keuangan dikatakan memiliki manfaat terhadap penggunanya ketika laporan keuangan disajikan tepat waktu.

Komitmen organisasi paling sering diartikan sebagai keinginan kuat untuk tetap sebagai anggota organisasi tertentu, keinginan untuk berusaha keras sesuai keinginan organisasi, keyakinan tertentu, dan penerimaan nilai dan tujuan organisasi. Laporan keuangan pemerintah merupakan komponen penting dalam mewujudkan akuntabilitas pengelolaan keuangan kepada publik. Fungsi informasi dalam laporan keuangan tidak akan memiliki manfaat jika penyajian dan penyampaian informasi keuangan tersebut tidak andal dan tidak tepat waktu Donaldson \& Davis (1991). Hasil penelitian Amalia (2014) dan Fransiska et al., (2015) menghasilkan komitmen organisasi berpengaruh terhadap keandalan pelaporan keuangan pemerintah daerah, Mutiana et al., (2017) dan Agung \& Gayatri (2018) menghasilkan komitmen organisasi berpengaruh terhadap kualitas laporan keuangan pemerintah daerah. Serta Eristanti et al., (2019) berpengaruh positif terhadap ketepatan waktu pelaporan keuangan. Berdasarkan penjelasan dan hasil penelitian terdahulu, maka dapat disimpulkan bahwa semakin tinggi tingkat komitmen seseorang dalam organisasi maka dapat meningkatkan timeliness pelaporan keuangan, sehingga dapat dirumuskan hipotesis sebagai berikut.

$\mathrm{H}_{1}$ : Komitmen organisasi berpengaruh positif terhadap ketepatan waktu pelaporan keuangan.

Menurut Agung \& Gayatri (2018) gaya kepemimpinan menunjukkan cara atau sikap bagaimana seorang pemimpin memberikan pengaruh kepada anggotanya untuk dapat mencapai tujuan bersama. Sikap dan perilaku anggota organisasi tercermin dari bagaimana gaya kepemimpinan seorang pemimpin sehingga gaya kepemimpinan yang baik yang dapat memotivasi anggotanya akan menjadikan organisasi lebih mudah dalam mencapai tujuannya dan anggota organisasi akan dapat menunjukkan kinerja yang lebih baik. Penelitian Pradipa (2016) dan Agung \& Gayatri (2018) menunjukkan bahwa gaya kepemimpinan bepengaruh pada kualitas laporan yang dihasilkan. Andriyani et al., (2016) menghasilkan gaya kepemimpinan berpengaruh signifikan terhadap penerapan transparansi pelaporan keuangan. Suarmika et al., (2016) menghasilkan gaya kepemimpinan dan sistem pengendalian internal memiliki pengaruh positif pada pelaksanaan penganggaran berbasis kinerja. Sehingga dapat disimpulkan bahwa 
semakin baik perilaku kepemimpinan maka tujuan organisasi dapat dicapai. Berdasarkan hasil penelitian terdahulu dapat dirumuskan hipotesis penelitian sebagai berikut.

$\mathrm{H}_{2}$ : Gaya kepemimpinan berpengaruh positif terhadap ketepatan waktu pelaporan keuangan.

Penerapan sistem akuntansi keuangan daerah digunakan untuk meningkatkan akuntabilitas dan keandalan pengelolaan laporan keuangan pemerintah daerah melalui penyusunan dan pengembangan standar akuntansi pemerintah daerah. Selain Standar Akuntansi Pemerintah (SAP), yang mempengaruhi informasi laporan keuangan pemerintah daerah adalah Sistem Akuntansi Keuangan Daerah. Untuk dapat menghasilkan laporan keuangan yang relevan, handal, dan dapat dipercaya, pemerintah daerah harus memiliki sistem akuntansi yang handal (Mardiasmo, 2018). Hasil riset Nurillah \& Muid (2014), Drama (2014), Murapi (2016) dan Mokoginta et al., (2017) menghasilkan sistem akuntansi keuangan daerah berpengaruh positif terhadap kualitas laporan keuangan. Astrawan et al., (2016) menghasilkan sistem informasi akuntansi berpengaruh positif dan signifikan terhadap ketepatwaktuan pelaporan keuangan pemerintah daerah. Serta Eristanti et al., (2019) menghasilkan sistem akuntansi keuangan daerah berpengaruh positif terhadap ketepatan waktu pelaporan keuangan. Sehingga dapat disimpulkan bahwa dengan adanya sistem akuntansi keuangan daerah, maka secara tidak langsung laporan keuangan akan mengikuti alur dari sistem baik manual ataupun yang sudah terkomputerisasi. Oleh karena itu, laporan keuangan akan selesai tepat waktu dan sesuai dengan aturan yang berlaku. Maka dirumuskan hipotesis penelitian sebagai berikut.

$\mathrm{H}_{3}$ : Sistem akuntansi keuangan daerah berpengaruh positif terhadap ketepatan waktu pelaporan keuangan.

Hasil penelitian Astrawan et al., (2016) diperoleh hasil riset bahwa sistem pengendalian internal berdampak positif pada ketepatan waktu, serta penelitian Rachmawati (2014) mengemukakan bahwa hasil riset pengendalian internal akuntansi berpengaruh positif pada ketepatan waktu, serta penelitian Mutiana et al., (2017) mendapatkan hasil berupa sistem pengendalian intern berpengaruh terhadap kualitas laporan keuangan. Serta Eristanti et al., (2019) menghasilkan sistem pengendalian intern memperlemah pengaruh komitmen organisasi terhadap ketepatan waktu. Dengan adanya pengendalian internal alhasil komitmen organisasi akan semakin tinggi. Sebab, laporan keuangan harusnya memenuhi mutu tinggi serta diselesaikan tepat waktu sesuai dengan freamwork yang telah distandarisasi. Jika sistem pengendalian intern diterapkan dengan baik alhasil laporan keuangan akan memiliki nilai informasi berguna, sehingga laporan keuangan dapat disajikan tepat waktu. Kemudian dikemukakan hipotesis riset sebagai berikut.

$\mathrm{H}_{4}$ : Sistem pengendalian intern memperkuat pengaruh komitmen organisasi terhadap ketepatan waktu laporan keuangan.

Hasil riset Pamilih (2014) mengemukakan bahwa gaya kepemimpinan berdampak signifikan pada kinerja auditor. Muis et al., (2020) mengemukakan yakni gaya kepemimpinan berdampak positif serta signifikan pada implementasi performance budgeting. Sementara itu, Afifah (2019) yang menyatakan bahwa gaya kepemimpinan tidak berpengaruh terhadap kualitas laporan keuangan 
pemerintah daerah. Memungkinkan pemimpin untuk memimpin organisasinya secara efektif serta mempunyai bawahan yang kompeten untuk menyusun atau mencatat laporan keuangan dan di support dari sistem pengendalian internal yang bermutu di dalam organisasi, sehingga bisa mencegah serta mendeteksi kecurangan serta mencapai tujuan kecurangan. Tata kelola yang baik tentang ini tercermin dalam laporan keuangan yang dapat diandalkan. Maka dapat dirumuskan hipotesis sebagai berikut.

$\mathrm{H}_{5}$ : Sistem pengendalian intern memperkuat pengaruh gaya kepemimpinan terhadap ketepatan waktu laporan keuangan.

Jika penerapan pengendalian intern berjalan dengan baik, maka laporan keuangan yang dihasilkan akan mempunyai nilai informasi yang baik. Dalam hal tertentu laporan keuangan sebagai sebuah informasi akan bermanfaat apabila informasi yang dikandungnya disediakan tepat waktu bagi pembuat keputusan. Jika terdapat penundaan yang tidak semestinya dalam pelaporan, maka informasi yang dihasilkan akan kehilangan relevansinya. Hasil riset Astrawan et al., (2016) menemukan bahwa sistem pengendalian internal berdampak positif pada ketepatan waktu, dan penelitian Mutiana et al., (2017) menciptakan yakni sistem pengendalian internal berdampak pada mutu informasi. Riset terkait pengendalian internal akuntansi berdampak positif signifikan pada ketepatan waktu pelaporan keuangan, seperti penelitian Rachmawati (2014). Penelitian Eristanti et al., (2019) menyebabkan sistem pengendalian internal menguatkan dampak sistem akuntansi keuangan daerah pada ketepatan waktu. Sistem pengendalian internal yang maksimal akan menguatkan hubungan antara sistem akuntansi keuangan daerah dengan ketepatan waktu pelaporan keuangan. Oleh sebab itu, berdasarkan riset sebelumnya, hipotesis penelitian yakni.

$\mathrm{H}_{6}$ : Sistem pengendalian intern memperkuat pengaruh sistem akuntansi keuangan daerah terhadap ketepatan waktu laporan keuangan.

\section{METODE PENELITIAN}

Penelitian ini merupakan penelitian kuantitatif serta termasuk dalam penelitian asosiatif. Populasi dalam penelitian ini merupakan pegawai bagian akuntansi 38 OPD (Organisasi Daerah Pemerintah) Provinsi Nusa Tenggara Barat yang terdiri dari Sekretariat, Inspektorat, Dinas, dan Badan. Teknik pengambilan sampel yang dipakai dalam riset ini merupakan menggunakan non-probability sampling dengan metode purpose sampling. Purposive sampling digunakan karena informasi yang akan diambil berasal dari sumber yang dipilih berdasarkan kriteria yang telah ditetapkan yaitu Pegawai yang melaksanakan fungsi akuntansi/ keuangan, Pegawai yang merupakan Pejabat Penatausahaan Keuangan (PPK), bendahara pengeluaran dan staf akuntansi yang menyusun laporan keuangan. Sampel yang diambil berjumlah tiga (3) responden yang berasal dari 38 OPD Provinsi Nusa Tenggara Barat. Sehingga, didapatkan jumlah sampel dalam penelitian ini berjumlah 114 responden.

Ada variabel eksogen, variabel endogen serta variabel moderasi dalam riset ini. Variabel eksogen adalah komitmen organisasi, gaya kepemimpinan dan sistem akuntansi keuangan daerah. Variabel endogen adalah ketepatanwaktu pelaporan keuangan. Sedangkan variabel moderasi adalah sistem pengendalian intern. Komitmen organisasi diukur dengan indikator yaitu Identifikasi, 
Keterlibatan dan Loyalitas. Gaya kepemimpinan diukur dengan indikator yaitu hubungan pemimpin dan bawahan, Menentukan hubungan dalam pemberian tugas, Menetapkan pola dan saluran komunikasi dan Menguraikan pentingnya pekerjaan. Sistem Akuntansi Keuangan Daerah diukur dengan indikator yaitu Kesesuaian sistem dengan SAP, Pengidentifikasian transaksi, Pencatatan transaksi, Bukti disetiap transaksi, Pencatatan kronologis, Pengklasifikasian transaksi, dan Laporan keuangan setiap periode. Ketepatan Waktu Pelaporan Keuangan diukur dengan indikator yaitu Tersedianya informasi saat dibutuhkan dan Laporan yang sistematis dan teratur. Sistem Pengendalian Intern diukur dengan indikator yaitu lingkungan pengendalian, penilaian resiko, kegiatan pengendalian, informasi dan komunikasi dan pemantauan pengendalian intern. Pengukuran variabel dalam penelitian ini menggunakan sakal likert dengan lima laternatif jawaban sebagai berikut, Sangat Tidak Setuju diberi skor $=1$; Tidak Setuju diberi skor $=2$; Cukup diberi skor $=3$; Setuju diberi skor $=4$; dan Sangat Setuju diberi skor $=5$.

Metode pengumpulan data dalam riset ini merupakan dengan memakai angket survey. Basis informasi riset ini merupakan data primer. Data primer dalam riset ini merupakan informasi yang didapat dengan mengedarkan angket pada responden yang menduduki jabatan di aspek yang berhubungan dengan pelaporan keuangan pada Organisasi Perangkat Daerah Provinsi Nusa Tengara Barat.

Kemudian menganalisis data yang terkumpul melalui statistik deskriptif serta analisa PLS- SEM. Statistik deskriptif merupakan statistik yang melukiskan kejadian ataupun karakter informasi. Dalam riset ini metode analisa informasi yang dipakai merupakan metode PLS-SEM dengan dorongan program Smart PLS versi 3. 0, PLS- SEM bermaksud buat mencoba perkiraan ikatan dampingi konstruk dengan memandang terdapat tidaknya ikatan ataupun akibat dampingi konstruk. Bagi Ghozali \& Latan (2015:47), langkah analisa mengenakan PLS- SEM wajib lewat 5 langkah, serta tiap langkah pengaruhi langkah berikutnya. Langkah analisa adalah metode analisis algoritma, menentukan metode resampling, menggambar diagram jalur, dan evaluasi model. Model persamaan yang digunakan adalah sebagai berikut.

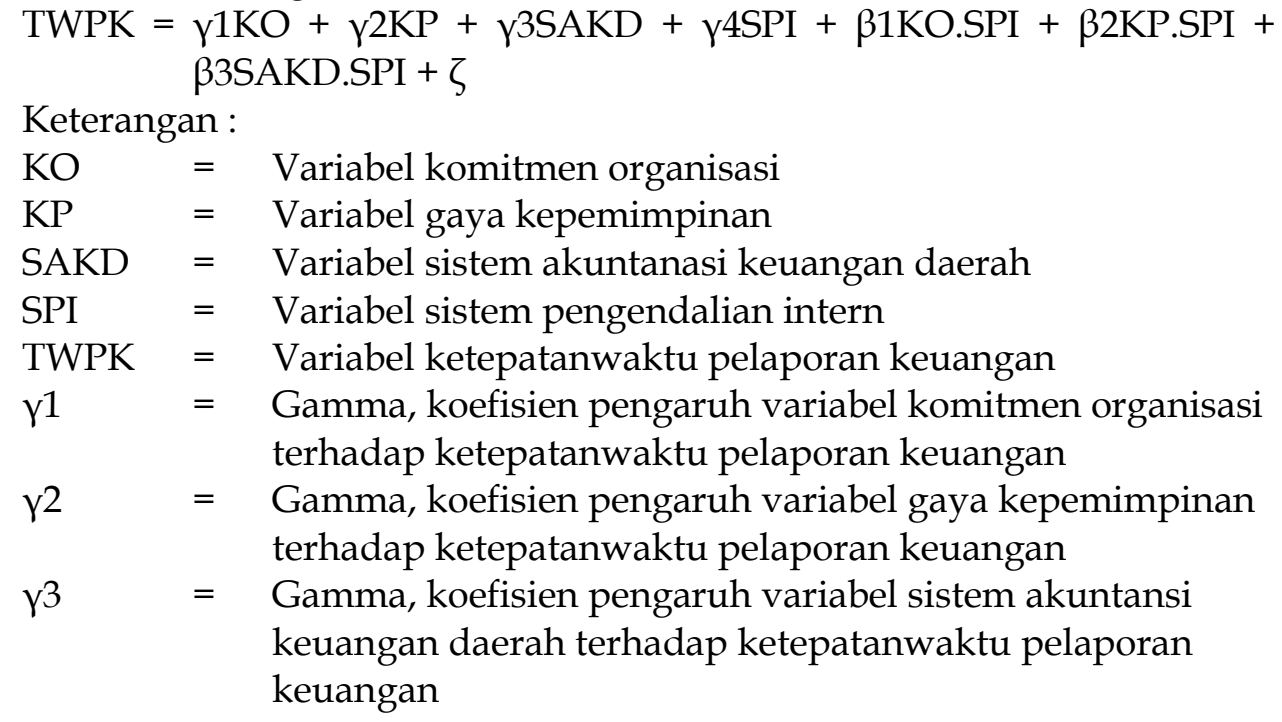




\begin{tabular}{|c|c|c|}
\hline$\gamma^{4}$ & $=$ & $\begin{array}{l}\text { Gamma, koefisien pengaruh variabel sistem pengendalian } \\
\text { intern terhadap ketepatanwaktu pelaporan keuanga }\end{array}$ \\
\hline$\beta 1$ & $=$ & $\begin{array}{l}\text { Beta, koefisien hubungan variabel komtimen organisasi } \\
\text { dengan sistem pengendalian intern }\end{array}$ \\
\hline$\beta 2$ & $=$ & $\begin{array}{l}\text { Beta, koefisien hubungan variabel gaya kepemimpinan } \\
\text { dengan sistem pengendalian intern }\end{array}$ \\
\hline$B 3$ & $=$ & $\begin{array}{l}\text { Beta, koefisien hubungan variabel sistem akuntansi } \\
\text { keuangan daerah dengan sistem pengendalian intern }\end{array}$ \\
\hline & 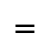 & Zeta, error terms atau galat model struktural. \\
\hline
\end{tabular}

\section{HASIL DAN PEMBAHASAN}

Data pada penelitian ini dikumpulkan dengan menyebarkan kuesioner pada 38 Organisasi Perangkat Daerah (OPD) Pemerintah Provinsi Nusa Tenggara Barat. jumlah kuesioner yang disebar kepada responden sebanyak 114 kuesioner. Namun kuesioner yang kembali sebanyak 99 kuesioner. Kuesioner yang tidak kembali sebanyak 15 kuesioner disebabkan karena keterlambatan surat disposisi yang dikeluarkan oleh OPD terkait dan beberapa OPD hanya mengisi 2 kuesioner dari jumlah 3 kuesioner yang di distribusikan.

Tabel 1. Distribusi dan Pengembalian Kuesioner

\begin{tabular}{lc}
\hline \multicolumn{1}{c}{ Keterangan } & Jumlah \\
\hline Kuesioner yang didistribusi & 114 \\
Kuesioner yang tidak kembali & 15 \\
Kuesioner yang kembali & 99 \\
Tingkat Pengembalian kuesioner & $86,8 \%$ \\
\hline
\end{tabular}

Sumber: Data Penelitian, 2021

Gambaran tentang karakteristik responden dalam penelitian ini meliputi jenis kelamin, umur, masa kerja, tingkat pendidikan, dan diklat/bimtek yang pernah diikuti. Responden dari penelitian ini sebanyak 99 orang. Hasil analisis deskriptif menunjukkan bahwa total nilai rata-rata untuk indikator dari variable komitmen organisasi berada pada angka 28,404 menunjukkan bahwa persepsi responden secara umum tentang komitmen organisasi yang diterapkan sudah sesuai dengan kebijakan dan peraturan terkait kinerja sehingga dapat dijalankan dengan baik oleh pelaku organisasi. Total nilai rata-rata untuk indikator dari variabel gaya kepemimpinan berada pada angka 16,646 menunjukkan bahwa persepsi responden secara umum tentang gaya kepemimpinan yang diterapkan sudah baik sesuai dengan pola perilaku dan strategi yang diharapkan sehingga dapat menghasilkan kualitas dan timeliness laporan keuangan yang baik. Total nilai rata-rata untuk indikator dari variabel SAKD berada pada angka 30,424 menunjukkan bahwa persepsi responden secara umum tentang SAKD yang diterapkan baik dan tertib sesuai standar-standar pelaksanaan pengelolaan keuangan.

Total nilai rata-rata untuk indikator dari variabel SPI berada pada angka 25,212 menunjukkan bahwa persepsi responden secara umum tentang SPI yang diterapkan Pemerintah Provinsi Nusa Tenggara Barat sudah baik dan tertib sesuai standar-standar pelaksanaan pengelolaan keuangan sehingga mampu mengontrol penyimpangan terhadap arah pencapaian tujuan organisasi. Total nilai rata-ata untuk indikator dari variabel ketepatan waktu pelaporan keuangan berada pada 
angka 25,505 menunjukkan bahwa persepsi responden secara umum tentang ketepatan waktu pelaporan keuangan telah dilaksanakan dengan baik sebagai wujud dari tanggung jawab dalam melakukan pengelolaan keuangan secara tepat waktu.

\section{Tabel 2. Karakteristik Responden}

\begin{tabular}{lcc}
\hline Keterangan & Jumlah & Persentase \\
\hline Jenis Kelamin & & \\
Laki-laki & 45 & $45,5 \%$ \\
Perempuan & 54 & $54,5 \%$ \\
Usia & & \\
$<25$ tahun & - & - \\
$25-30$ tahun & 5 & $5 \%$ \\
$31-40$ tahun & 34 & $34,4 \%$ \\
$41-50$ tahun & 47 & $47,5 \%$ \\
$>50$ tahun & 13 & $13,1 \%$ \\
Masa kerja & & \\
$<5$ tahun & - & \\
$5-10$ tahun & 13 & $13,1 \%$ \\
$>10$ tahun & 86 & $86,9 \%$ \\
Pendidikan terakhir & & \\
SLTA & 10 & $10 \%$ \\
Diploma & 5 & $5 \%$ \\
Sarjana & 74 & $75 \%$ \\
Pasca Sarjana & 10 & $10 \%$ \\
diklat/bimtek yang pernah diikuti & & \\
tidak pernah & 5 & $5 \%$ \\
1 kali & 15 & $15,1 \%$ \\
2 kali & 27 & $27,3 \%$ \\
3 kali & 31 & $21,3 \%$ \\
$>3$ kali & 21 & \\
\hline
\end{tabular}

Sumber: Data Penelitian, 2021

Berikut hasil statistik deskriptif variabel komitmen organisasi, gaya kepemimpinan, sistem akuntansi keuangan daerah, ketepatan waktu pelaporan keuangan, dan sistem pengendalian intern.

Tabel 3. Statistik Deskriptif

\begin{tabular}{|c|c|c|c|c|c|}
\hline & $\mathrm{N}$ & Min & Max & Mean & Standar Deviation \\
\hline Komitmen Organisasi & 99 & 20,000 & 35,000 & 28,404 & 4,191 \\
\hline Gaya Kepmimpinan & 99 & 11,000 & 20,000 & 16,646 & 2,520 \\
\hline Akuntansi & & & & & \\
\hline $\begin{array}{l}\text { Keuangan Daerah } \\
\text { Sistem Pengendalian }\end{array}$ & 99 & 22,000 & 35,000 & 30,424 & 3,622 \\
\hline $\begin{array}{l}\text { Intern } \\
\text { Ketepatanwaktu }\end{array}$ & 99 & 18,000 & 30,000 & 25,212 & 3,444 \\
\hline Pelaporan Keuangan & 99 & 15,000 & 30,000 & 25,505 & 3,265 \\
\hline
\end{tabular}

Sumber: Data Penelitian, 2021

Validitas diskriminan berhubungan dengan prinsip bahwa pengukurpengukur (manifest variabel) konstruk yang berbeda seharusnya tidak berkorelasi dengan tinggi. Discriminant Validity dapat dievaluasi dengan melihat nilai cross loading yaitu loading indikator ke konstruk yang diukur lebih besar dari pada 
loading ke konstruk lain atau dengan melihat akar kuadrat Average Variance Extracted (AVE) lebih besar dari korelasi antar konstruk (Ghozali \& Latan, 2015:74). Hasil pengujian validitas diskriminan sebagai berikut.

Tabel 4. Cross Loading

\begin{tabular}{|c|c|c|c|c|c|c|c|c|}
\hline & \multicolumn{3}{|c|}{$\mathrm{KO} * \mathrm{~S}$} & \multicolumn{5}{|c|}{ SAKD } \\
\hline & $\mathrm{KO}$ & PI & $\mathrm{KP}$ & KP*SPI & SAKD & *SPI & SPI & TWPK \\
\hline $\mathrm{KO}^{*} \mathrm{SPI}$ & 0,390 & 1.000 & 0,258 & 0,561 & 0,198 & 0,497 & 0,175 & 0,173 \\
\hline KO1 & 0,780 & 0,235 & 0,397 & 0,182 & 0,353 & 0,152 & 0,312 & 0,397 \\
\hline KO2 & 0,805 & 0,267 & 0,283 & 0,242 & 0,298 & 0,118 & 0,301 & 0,386 \\
\hline KO3 & 0,785 & 0,270 & 0,327 & 0,221 & 0,291 & 0,194 & 0,324 & 0,406 \\
\hline KO4 & 0,785 & 0,320 & 0,521 & 0,143 & 0,303 & 0,161 & 0,285 & 0,357 \\
\hline KO5 & 0,736 & 0,437 & 0,212 & 0,218 & 0,208 & 0,226 & 0,320 & 0,372 \\
\hline KO6 & 0,763 & 0,251 & 0,298 & 0,202 & 0,236 & 0,083 & 0,294 & 0,340 \\
\hline KO7 & 0,772 & 0,336 & 0,455 & 0,174 & 0,426 & 0,217 & 0,430 & 0,453 \\
\hline $\mathrm{KP} * \mathrm{SPI}$ & 0,254 & 0,561 & 0,197 & 1.000 & 0,219 & 0,614 & 0,038 & 0,056 \\
\hline KP1 & 0,423 & 0,229 & 0,744 & 0,152 & 0,332 & 0,186 & 0,335 & 0,187 \\
\hline KP2 & 0,500 & 0,171 & 0,912 & 0,155 & 0,391 & 0,165 & 0,374 & 0,451 \\
\hline KP3 & 0,355 & 0,323 & 0,885 & 0,226 & 0,468 & 0,196 & 0,306 & 0,235 \\
\hline KP4 & 0,243 & 0,205 & 0,802 & 0,151 & 0,489 & 0,285 & 0,276 & 0,298 \\
\hline SAKD*SPI & 0215 & 0,497 & 0,241 & 0,614 & 0,206 & 1.000 & 0,194 & 0,168 \\
\hline SAKD1 & 0,396 & 0,112 & 0,399 & 0,218 & 0,729 & 0,251 & 0,346 & 0,345 \\
\hline SAKD2 & 0,355 & 0,120 & 0,248 & 0,280 & 0,716 & 0,271 & 0,385 & 0,331 \\
\hline SAKD3 & 0,314 & 0,154 & 0,261 & 0,229 & 0,700 & 0,216 & 0,440 & 0,345 \\
\hline SAKD4 & 0,269 & 0,127 & 0,417 & 0,078 & 0,756 & 0,051 & 0,414 & 0,288 \\
\hline SAKD5 & 0,243 & 0,125 & 0,398 & 0,024 & 0,798 & $-0,007$ & 0,529 & 0,404 \\
\hline SAKD6 & 0,253 & 0,180 & 0,369 & 0,176 & 0,817 & 0,174 & 0,479 & 0,466 \\
\hline SAKD7 & 0,272 & 0,195 & 0,474 & 0,153 & 0,702 & 0,134 & 0,415 & 0,439 \\
\hline SPI1 & 0,360 & 0,227 & 0,274 & 0,099 & 0,452 & 0,170 & 0,798 & 0,625 \\
\hline SPI2 & 0,352 & 0,119 & 0,293 & 0,008 & 0,475 & 0,069 & 0,812 & 0,470 \\
\hline SPI3 & 0,392 & 0,111 & 0,293 & $-0,002$ & 0,393 & 0,223 & 0,821 & 0,550 \\
\hline SPI4 & 0,320 & 0,163 & 0,275 & 0,011 & 0,401 & 0,122 & 0,832 & 0,491 \\
\hline SPI5 & 0,264 & 0,096 & 0,426 & $-0,011$ & 0,563 & 0,126 & 0758 & 0,454 \\
\hline SPI6 & 0,315 & 0,103 & 0,306 & 0,055 & 0,501 & 0,192 & 0,757 & 0,573 \\
\hline TWPK1 & 0,449 & 0,144 & 0,334 & 0,035 & 0,336 & 0,155 & 0,658 & 0,782 \\
\hline TWPK2 & 0,429 & 0,226 & 0,335 & 0,043 & 0,371 & 0,162 & 0,631 & 0,828 \\
\hline TWPK3 & 0,366 & 0,114 & 0,277 & 0,040 & 0,477 & 0,133 & 0,500 & 0,828 \\
\hline TWPK4 & 0,400 & 0,069 & 0,287 & 0,059 & 0,541 & 0,067 & 0,485 & 0,817 \\
\hline TWPK5 & 0,468 & 0,117 & 0,359 & 0,036 & 0,466 & 0,112 & 0,494 & 0,900 \\
\hline TWPK6 & 0,376 & 0,173 & 0,304 & 0,068 & 0,372 & 0,197 & 0,531 & 0,812 \\
\hline
\end{tabular}

Sumber: Data Penelitian, 2021

Kriteria validity dan reliabilitas juga dapat dilihat dari nilai reliabilitas suatu konstruk dan nilai average variance extracted (AVE) dari masing-masing konstruk. Konstruk yang baik apabila memiliki nilai reliabilitas yang tinggi jika nilainya diatas 0,70 dan AVE berada diatas 0,50 (Ghozali \& Latan, 2015:75). Berikut ini hasil pengujian composite reliability dan AVE pada seluruh variabel adalah sebagai berikut. 
Tabel 5. Nilai Composite Reliability dan AVE

\begin{tabular}{lcl}
\hline & Composite Reliability & AVE \\
\hline KO & 0,913 & 0,601 \\
KP & 0,904 & 0,703 \\
SAKD & 0,898 & 0,558 \\
TWPK & 0,929 & 0,686 \\
SPI & 0,912 & 0,635 \\
Efek Moderasi 1 & 1,000 & 1,000 \\
Efek Moderasi 2 & 1,000 & 1,000 \\
Efek Moderasi 3 & 1,000 & 1,000 \\
\hline
\end{tabular}

Sumber: Data Penelitian, 2021

R-square, koefisien determinasi struktur endogen, dipakai buat melihat keahlian variabel eksogen dalam menjelaskan variabel endogen. Bagi Chin (1998), nilai R-kuadrat dalam (Ghozali \& Latan, 2015:78) berturut-turut adalah 0,67 (baik), 0,33 (sedang), dan 0,19 (lemah). Nilai R-squared tercantum pada Tabel 4 di bawah ini.

Tabel 6. Nilai R-Squares

\begin{tabular}{lc}
\hline & R-Squares \\
\hline TWPK & 0,525 \\
\hline Sumber: Data Penelitian, 2021 &
\end{tabular}

Effect size ( $f$ square) dihitung sebagai nilai absolut kontribusi individual setiap variabel eksogen pada nilai R-square variabel endogen. Predictive relevance (Q square) digunakan untuk mengukur seberapa baik nilai observasi dihasilkan oleh model dan juga estimasi parameternya atau mengetahui kapabilitas prediksi dengan prosedur blindfolding (Ghozali \& Latan, 2015:81). Nilai Q square > 0, menunjukkan bahwa model memiliki predictive relevance, sedangkan $\mathrm{Q}$ square $<0$, menunjukkan bahwa model kurang memiliki predictive relevance (Ghozali \& Latan, 2015:81). Lebih lanjut Ghozali \& Latan (2015:80) menyebutkan bahwa dalam kaitannya dengan $\mathrm{f}$ square, perubahan $\mathrm{Q}$ square memberikan dampak relatif terhadap model struktural, dimana Q square 0,02 (lemah), 0,15 (moderate) dan 0,35 (kuat).

Tabel 7. Nilai Effect Size

\begin{tabular}{lc}
\hline \multicolumn{1}{c}{ Variabel } & TWPK \\
\hline Komitmen Organisasi & 0,090 \\
Gaya Kepmimpinan & 0,001 \\
Sistem Akuntansi Keuangan Daerah & 0,022 \\
Sistem Pengendalian Intern & 0,270 \\
Efek Moderasi 1 & 0,001 \\
Efek Moderasi 2 & 0,006 \\
Efek Moderasi 3 & 0,002 \\
\hline
\end{tabular}

Sumber: Data Penelitian, 2021

Nilai Q2 Predictive Relevance diperoleh dari perhitungan sebagai berikut.

$\mathrm{Q} 2=1-(1-\mathrm{R} 2)$

$\mathrm{Q} 2=1-(1-0,525)$

$\mathrm{Q} 2=1-0,475=0,525$

Berdasarkan hasil perhitungan di atas diperoleh nilai Q2 predictive relevance sebesar 0,525 atau nilai Q2 predictive relevance $>0$ yang berarti model penelitian ini 
mempunyai predictive relevance. Berikut disajikan hasil analisis koefisien jalur (path coefficient).

Tabel 8. Path Coefficient

\begin{tabular}{|c|c|c|c|c|c|c|}
\hline Hipotesis & $\begin{array}{l}\text { Pengaruh } \\
\text { Langsung }\end{array}$ & $\begin{array}{l}\text { Original } \\
\text { Sampel }\end{array}$ & $\begin{array}{c}\mathrm{T} \\
\text { statistik }\end{array}$ & $\begin{array}{c}\mathrm{P} \\
\text { Value }\end{array}$ & \multicolumn{2}{|c|}{ Keterangan } \\
\hline $\mathrm{H} 1$ & KO -> TWPK & 0,179 & 2,748 & 0,006 & Signifikan & diterima \\
\hline $\mathrm{H} 2$ & KP -> TWPK & 0,025 & 0,177 & 0,554 & $\begin{array}{c}\text { Tidak } \\
\text { Signifikan }\end{array}$ & ditolak \\
\hline $\mathrm{H} 3$ & SAKD -> TWPK & 0,094 & 1,336 & 0,126 & $\begin{array}{c}\text { Tidak } \\
\text { Signifikan }\end{array}$ & ditolak \\
\hline $\mathrm{H} 4$ & Efek Moderasi 1 & $-0,023$ & 0,154 & 0,571 & $\begin{array}{c}\text { Tidak } \\
\text { Signifikan }\end{array}$ & ditolak \\
\hline H5 & Efek Moderasi 2 & $-0,074$ & 0,466 & 0,348 & $\begin{array}{c}\text { Tidak } \\
\text { Signifikan }\end{array}$ & ditolak \\
\hline H6 & Efek Moderasi 3 & 0,049 & 0,300 & 0,461 & $\begin{array}{c}\text { Tidak } \\
\text { Signifikan }\end{array}$ & ditolak \\
\hline
\end{tabular}

Sumber: Data Penelitian, 2021

Berdasarkan nilai path coefficient yang diperoleh maka persamaan dari model struktural (inner model) penelitian ini disajikan sebagai berikut.

TWPK $=2,791 \mathrm{KO}+0,259 \mathrm{KP}+1,379 \mathrm{SAKD}+5,295 \mathrm{SPI}+0,212 \mathrm{KO} . \mathrm{SPI}+$ 0,605 KP.SPI + 0,411 SAKD.SPI

Hipotesis pertama $\left(\mathrm{H}_{1}\right)$ menunjukkan komitmen organisasi berpengaruh positif dan signifikan terhadap ketepatanwaktu pelaporan keuangan, dimana hipotesis diterima. Hasil penelitian ini mendukung penelitian Amalia (2014) dan Fransiska et al., (2015) menghasilkan komitmen organisasi berpengaruh terhadap keandalan pelaporan keuangan pemerintah daerah, Mutiana et al., (2017) dan Agung \& Gayatri (2018) menghasilkan komitmen organisasi berpengaruh terhadap kualitas laporan keuangan pemerintah daerah. Serta Eristanti et al., (2019) berpengaruh positif terhadap ketepatan waktu pelaporan keuangan. namun penelitian ini berbeda dengan penelitian yang dilakukan Rachmawati (2014) yang mendapatkan hasil komitmen organisasi tidak berpengaruh signifikan terhadap ketepatan waktu.

Hipotesis kedua $\left(\mathrm{H}_{2}\right)$ menyatakan gaya kempimpinan berpengaruh positif dan tidak signifikan terhadap ketepatanwaktu pelaporan keuangan, dimana hipotesis ditolak. Penelitian ini sejalan dengan hasil penelitian Afifah (2019) mendapatkan hasil gaya kepemimpinan tidak berpengaruh terhadap kualitas laporan keuangan pemerintah daerah. Penelitian ini bertolak belakang dengan penelitian Pradipa (2016) dan Agung \& Gayatri (2018) yang menghasilkan gaya kepemimpinan berpengaruh positif dan signifikan terhadap kualitas laporan keuangan.

Hipotesis ketiga $\left(\mathrm{H}_{3}\right)$ menyatakan sistem akuntansi keuangan daerah berpengaruh positif dan tidak signifikan terhadap ketepatanwaktu pelaporan keuangan, dimana hipotesis ditolak. Perihal ini dikarenakan penerapan sistem akuntansi keuangan daerah baik yang manual maupun yang terkomputerisasi sedang kurang dimengerti oleh pengelola finansial, dan pengelola finansial memerlukan durasi untuk membuat laporan finansial. Penelitian ini mendukung penelitian Latifah (2015) yang menghasilkan sistem akuntansi keuangan daerah 
tidak berpengaruh terhadap kualitas laporan keuangan. akan tetapi, penelitian ini tidak sesuai dengan penelitian Drama (2014) dan Murapi (2016) yang menghasilkan sistem akuntansi keuangan daerah berpengaruh signifikan terhadap kualitas laporan keuangan.

Hipotesis keempat $\left(\mathrm{H}_{4}\right)$ tentang sistem pengendalian intern memperkuat pengaruh komitmen organisasi terhadap ketepatanwaktu pelaporan keuangan, dimana hipotesis ditolak. Dalam konteks teori stewardship dimana laporan keuangan yang berkualitas yaitu laporan yang sesuai dengan Standar Akuntansi Pemerintah (SAP) yang berlaku. sehingga dengan adanya komitmen organisasi dan sistem pengendalian intern yang baik, pengelola keuangan akan mampu melaksakanan laporan keuangan yang berkualitas dan tepat waktu. Nmaun dalam penelitian ini sistem pengendalian intern tidak mampu memperkuat pengaruh komitmen organisasi terhadap ketepatanwaktu pelaporan keuangan.

Hipotesis kelima $\left(\mathrm{H}_{5}\right)$ tentang sistem pengendalian intern memperkuat pengaruh gaya kepmeimpinan terhadap ketepatanwaktu pelaporan keuangan, dimana hipotesis ditolak. Sistem pengendalian intern yang memadai dapat berperan dalam memaksimalkan gaya kepemimpinan. Dibuktikan dalam teori penatalayanan (stewardship theory) yang menjelaskan bahwa sebagai pemimpin yang memiliki kendali dan pengaruh atas kinerja para pegawainya untuk menghasilkan laporan keuangan, di mana pimpinan yang sepenuhnya bertanggung jawab kepada masyarakat dalam mempertanggungjawabkan amanah yang telah diberikan oleh masyarakat, serta dalam menyajikan laporan keuangan yang berkualitas dan tepat waktu. Sehingga dengan sistem pengendalian intern dan gaya kepemimpinan yang diterapkan secara maksimal akan berdampak pada peningkatan laporan keuangan yang menjadi semakin andal. Akan tetapi, sistem pengedalian intern belum cukup memadai dalam memoderasi gaya kepemimpinan terhadap ketepatanwaktu pelaporan keuangan. Penyebabnya adalah belum mengikuti prinsip-prinsip pengelolaan yang baik, yaitu keterbukaan (transparansi), partisipasi dan kemandirian oleh setiap pegawai. Namun pada penelitian ini sistem pengendalian intern tidak mampu memperkuat pengaruh gaya kepemimpinan terhadap ketepatanwaktu pelaporan keuangan.

Hipotesis keenam $\left(\mathrm{H}_{6}\right)$ tentang sistem pengendalian intern memperkuat pengaruh sistem akuntansi keuangan daerah terhadap ketepatanwaktu pelaporan keuangan, dimana hipotesis ditolak. Sesuai konteks teori kepatuhan (compliance theory), pengelola keuangan pemerintah Provinsi Nusa Tenggara Barat belum maksimal menerapkan sistem pengendalian intern dan sistem akuntansi keuangan daerah. Sistem akuntansi keuangan daerah yang sudah sesuai dengan standar akuntansi pemerintah akan lebih memberikan kepercayaan kepada pengguna laporan keuangan. Namun pada penelitian ini sistem pengendalian intern tidak mampu memperkuat pengaruh sistem akuntansi keuangan daerah terhadap ketepatanwaktu pelaporan keuangan.

Pengujian efek moderasi dalam PLS digunakan untuk menunjukkan interaksi antara variabel eksogen (prediktor) dengan variabel moderator dalam mempengaruhi variabel endogen (Ghozali \& Latan, 2015:163). Ada empat jenis efek moderasi yang ditimbulkan dari hubungan moderasi yaitu pure moderasi, quasi moderasi, homologiser moderasi dan predictor moderasi (Sugiyono, 2018). 
HIDNI, B. M., SANTOSO, B., \& PITURINGSIH, E. DETERMINAN KETEPATAN WAKTU...

Tabel 9. Total Effect

\begin{tabular}{|c|c|c|c|c|c|c|}
\hline Hipotesis & $\begin{array}{l}\text { Pengaruh } \\
\text { Langsung }\end{array}$ & $\begin{array}{l}\text { Original } \\
\text { Sampel }\end{array}$ & $\begin{array}{c}\mathrm{T} \\
\text { statistik }\end{array}$ & $\begin{array}{c}\mathrm{P} \\
\text { Value }\end{array}$ & \multicolumn{2}{|c|}{ Keterangan } \\
\hline & SPI -> TWPK & 0,327 & 5,295 & 0,000 & Signifikan & \\
\hline $\mathrm{H} 4$ & Efek Moderasi 1 & $-0,023$ & 0,147 & 0,578 & $\begin{array}{c}\text { Tidak } \\
\text { Signifikan }\end{array}$ & $\begin{array}{l}\text { Predictor } \\
\text { Moderasi }\end{array}$ \\
\hline H5 & Efek Moderasi 2 & $-0,074$ & 0,420 & 0,378 & $\begin{array}{c}\text { Tidak } \\
\text { Signifikan }\end{array}$ & $\begin{array}{l}\text { Predictor } \\
\text { Moderasi }\end{array}$ \\
\hline H6 & Efek Moderasi 3 & 0,049 & 0,285 & 0,472 & $\begin{array}{c}\text { Tidak } \\
\text { Signifikan }\end{array}$ & $\begin{array}{l}\text { Predictor } \\
\text { Moderasi }\end{array}$ \\
\hline
\end{tabular}

Sumber: Data Penelitian, 2021

Temuan penelitian mendukung konsep teori penatalayanan (Stewardship Theory), dikarenakan pemerintah telah berusaha membuat laporan keuangan yang berkualitas dan tepat waktu. Selain itu, gaya kepemimpinan yang dilakukan secara jelas dan efektif. Namun hasil penelitian ini belum dapat mendukung teori penatalayanan (Stewardship Theory), dikarenakan pemimpin kurang efektif dalam mempengaruhi kinerja bawahannya untuk mencapai tujuan organisasi tersebut. Serta kurangnya komunikasi antara pimpinan dan bawahan, laporan finansial yang diperoleh tidak bermutu dan tepat waktu. Sistem akuntansi finansial daerah sesuai dengan SAP (Standar Akuntansi Pemerintah) akan membuat laporan keuangan menjadi berkualitas, karena bebas dari kesalahan penyajian laporan keuangan. Namun hasil riset ini belum dapat mendukung teori kepatuhan (compliance theory), dikarenakan Pemerintah Provinsi Nusa Tenggara Barat belum maksimal dalam menerapkan sIstem akuntanasi keuangan daerah dan sistem pengendalian intern. Hal ini disebabkan karena masih kurangnya pemahaman dalam membuat pelaporan keuangan baik secara manual maupun terkomputerisasi. Penelitian ini menunjukkan bahwa sistem pengendalian intern memperlemah dampak komitmen organisasi, gaya kepemimpinan serta sistem akuntansi keuangan daerah pada ketepatanwaktu, hal ini dikarenakan sistem pengendalian intern membuat ruang gerak pengelola keuangan maupun pimpinan menjadi sempit dan beban kerja yang berat dan bertambah, karena banyaknya aturan-aturan yang harus diperhatikan sesuai dengan pedoman sistem akuntansi pemerintah (SAP).

\section{SIMPULAN}

Hasil penelitian menunjukkan bahwa komitmen organisasi berpengaruh positif dan signifikan terhadap ketepatanwaktu laporan keuangan, gaya kepemimpinan dan sistem akuntansi keuangan daerah berpengaruh positif dan tidak signifikan terhadap ketepatanwaktu laporan keuangan, dan sistem pengendalian intern tidak mampu memperkuat pengaruh komitmen organisasi, gaya kepemimpinan dan sistem akuntansi keuangan daerah terhadap ketepatanwaktu pelaporan keuangan.

Berdasarkan hasil dan kesimpulan, saran untuk penelitian selanjutnya dapat diberikan dengan melihat faktor-faktor yang mempengaruhi ketepatan waktu laporan keuangan, seperti tata kelola pemerintahan yang baik dan tingkat pendidikan, untuk merumuskan variabel penelitian. Objek penelitian dapat diperluas, seperti penelitian 2 atau 3 pemerintah kabupaten/kota. Meneliti 2 atau 
$3 \mathrm{kab} /$ kota dapat menjadi penelitian multidimensi, karena hasil penelitian dalam

$1 \mathrm{kab} /$ kota tidak mungkin sama.

\section{REFERENSI}

Afifah. (2019). Pengaruh Standar Akuntansi Pemerintah, Sistem Pengendalian Internal, Kompetensi Sumber Daya Manusia Dan Gaya Kepemimpinan Terhadap Kualitas Laporan Keuangan Pemerintah Daerah (Studi Empiris Pada Organisasi Perangkat Daerah Kabupaten Purworejo).

Agung, T. M., \& Gayatri. (2018). Analisis Faktor-Faktor Yang Mempengaruhi Kualitas Laporan Keuangan Pemerintah Daerah Kabupaten Karangasem. EJurnal Akuntansi, 23, 1253. Https://Doi.Org/10,24843/Eja.2018.V23.I02.P17

Allen, N., Meyer, P., \& Smith, C. (1993). Commitment To Organizations And Occupations: Extension And Test Of A Three Component Conceptualization. Journal Of Applied Psychology, 78, 4.

Amalia, I. (2014). Analisis Pengaruh Kapasitas Sumber Daya Manusia, Pemanfaatan Teknologi Informasi, Pengendalian Intern Akuntansi Dan Komitmen Organisasi Terhadap Nilai Informasi Pelaporan Keuangan Pemerintah Daerah (Studi Pada Kabupaten Way Kanan).

Andriyani, L., Emrinaldi, \& Dp, N. (2016). Pengaruh Tekanan Eksternal, Komitmen Manajemen, Ketidakpastian Lingkungan, Gaya Kepemimpinan, Dan Aksesibilitas Laporan Keuangan Terhadap Penerapan Transparansi Pelaporan Keuangan (Survei Pada Satuan Kerja Perangkat Daerah Pemerintah Kabupaten Pelalawan). 3, 204218.

Astrawan, K. P., Wahyuni, M. A., \& Herawati, N. T. (2016). Pengaruh Sistem Informasi Akuntansi, Kapasitas Sumber Daya Manusia, Pengendalian Intern Dan Pengawasan Keuangan Pemerintah Daerah Terhadap Ketepetwaktuan Pelaporan Keuangan Pemerintah Daerah Pada Skpd Kabupaten Buleleng. Jurnal Ilmiah Mahasiswa Akuntansi, 6(3), 53-64.

Asysyihatul Latifah. (2015). Pengaruh Penerapan Standar Akuntansi Pemerintah, Sistem Akuntasi Keuangan Daerah, Kompetensi Sumber Daya Manusia Dan Sistem Pengendalian Internal Terhadap Kualitas Informasi Laporan Keuangan Daerah. Jurnal Ilmu \& Riset Akuntansi, 15.

Donaldson, L., \& Davis, J. H. (1991). Stewardship Theory Or Agency Theory: Ceo Covernance And Shareholders Return. Australian Journal Of Management, 16(1).

Drama, H. (2014). Pengaruh Penerapan Sistem Akuntansi Keuangan Daerah Terhadap Kualitas Informasi Laporan Keuangan Dengan Sistem Pengendalian Intern Sebagai Variabel Intervening (Studi Empiris Pada Skpd Kota Solok).

Eristanti, Baiq Dwi Apryana, Hermanto, \& Putra, I. N. N. A. (2019). Sistem Pengendalian Intern Memoderasi Pengaruh Komitmen Organisasi, Sistem Akuntansi Keuangan Daerah Pada Ketepatanwaktu Pelaporan Keuangan. EJurnal Akuntansi, 26(1), 622-650,

Fransiska, Nur Azlina, \& Susilatri. (2015). Pengaruh Sumber Daya Manusia, Pengawasan Keuangan Daerah, Pemanfaatan Teknologi Informasi Dan Komitmen Organisasi Terhadap Keandalan Pelaporan Keuangan Pemerintah Daerah (Studi Pada Satuan Kerja Perangkat Daerah Kabupaten Labuhan Batu). Journal Of Chemical Information And Modeling, 53(9), 1689-1699. 
Ghozali, I., \& Latan, H. (2015). Partial Least Square Konsep Teknik Dan Aplikasi Menggunakan Program Smartpls 3.0 (Kedua). Badan Penerbit Universitas Diponegoro.

Herniyasa, H. (2014). Pengaruh Penerapan Gaya Kepemimpinan Dan Good University Governance Terhadap Kualitas Laporan Keuangan ( Survey Pada Politeknik Negeri Bandung ). 174-182.

Kelman, H. C. (1966). Compliance, Identifikasi And Internalization:Three Process Of Attitude Change (Mcgrawhill (Ed.)).

Kosegeran, A. I., Kalangi, L., \& Wokas, H. (2016). Analisis Faktor-Faktor Yang Mempengaruhi Keandalan Dan Ketepatan Laporan Keuangan Satuan Kerja Perangkat Daerah Pada Pemerintah Kabupaten Minahasa Tenggara. Accountability, 5(2), 178. Https://Doi.Org/10,32400/Ja.14434.5.2.2016.178190

Lunenburg. (2012). Compliance Theory And Organizational Efektiveness. International Journal Of Scholarly Academic Intellectual Diversity, 14, 1.

Mardiasmo. (2018). Akuntansi Sektor Publik. Andi.

Miharja, E. S., Handajani, L., \& Furkan, L. M. (2020). Faktor-Faktor Yang Mempengaruhi Keandalan Dan Ketepatan Waktu Pelaporan Keuangan Pada Organisasi Perangkat Daerah Kabupaten Sumbawa Barat. Indonesia Accounting Journal, 2(2), 148. Https://Doi.Org/10,32400/Iaj.28818

Mokoginta, N., Lambey, L., \& Pontoh, W. (2017). Pengaruh Sistem Pengendalian Intern Dan Sistem Akuntansi Keuangan Daerah Terhadap Kualitas Laporan Keuangan Pemerintah. Going Concern : Jurnal Riset Akuntansi, 12(2), 874-890, Https:/ / Doi.Org/10,32400/Gc.12.2.18282.2017

Mowday, R. T., Porter, L. W., \& Steers, R. M. (1979). Employee-Organization Linkages: The Psychology Of Commitment, Absenteeism, And Turnover. Academic Press.

Muis, A., M. Furkan, L., \& Pituringsih, E. (2020). Determinan Penerapan Anggaran Berbasis Kinerja Pada Badan Layanan Umum Rumah Sakit Se-Pulau Sumbawa. E-Jurnal Akuntansi, 30(10), 2657.

Murapi, I. (2016). Faktor-Faktor Yang Mempengaruhi Kualitas Informasi Laporan Keuangan Pemerintah Daerah (Studi Empiris Pada Skpd Di Kabupaten Lombok Tengah). Jurnal Akuntansi Kompetif, 2(3), 102-107.

Mutiana, L., Diantimala, Y., \& Zuraida, Z. (2017). Pengaruh Sistem Pengendalian Intern, Teknologi Informasi, Kualitas Sumber Daya Manusia Dan Komitmen Organisasi Terhadap Kualitas Laporan Keuangan (Studi Pada Satker Di Lingkungan Kementerian Agama Kabupaten Aceh Utara). Jurnal Perspektif Ekonomi Darussalam, 3(2), 151-167.

Nurillah, A. S., \& Muid, D. (2014). Pengaruh Kompetensi Sumber Daya Manusia, Penerapan Sistem Akuntansi Keuangan Daerah (Sakd), Pemanfaatan Teknologi Informasi, Dan Sistem Pengendalian Intern Terhadap Kualitas Laporan Keuangan Pemerintah Daerah (Studi Empiris Pada Skpd Kota Depok). Journal Of Accounting, 3(2), 1-13.

Pamilih, I. (2014). Pengaruh Independensi, Gaya Kepemimpinan, Komitmen Organisasi Dan Pemahaman Good Governance Terhadap Kinerja Auditor Pemeritah (Studi Empiris Pada Kantor Bpkp Perwakilan Yogyakarta). Jurnal Universitas Muhamadiyah Surakarta, 1-16.

Peraturan Pemerintah Nomor 60 Tahun 2008. 
Peraturan Pemerintah Republik Indonesia Nomor 71 Tahun 2010 Tentang Sistem Akuntansi Pemerintah. (N.D.). 9(1), 76-99.

Pradipa, N. A. (2016). Hubungan Sistem Pengendalian Intern Dan Pemerintah Daerah (Studi Pada Skpd Provinsi Bali) Fakultas Ekonomi Dan Bisnis. Universitas Udayana, Bali, Indonesia Pendahuluan Reformasi Birokrasi Bertujuan Untuk Menciptakan Birokrasi Pemerintah Yang Profesio. 9, 2695-2722.

Prof. Dr. H. Imam Ghozali, M. C. A. (2017). Aplikasi Analisisi Multivaruete (8 (Ed.)). Badan Penerbit Universitas Diponegoro.

Rachmawati, A. (2014). Pengaruh Kapasitas Sumber Daya Manusia, Pemanfaatan Teknologi Informasi, Komitmen Organisasi Dan Pengendalian Intern Akuntansi Terhadap Keterandalan Dan Ketepatwaktuan Pelaporan Keuangan Pemerintah Daerah (Studi Pada Dinas Pendapatan, Pengelolaan Keuangan.

Rosalin, F., \& Kawedar, W. (2011). Faktor-Faktor Yang Mempengaruhi Keandalan Dan Timeliness Pelaporan Keuangan Badan Layanan Umum (Studi Pada Blu Di Kota Semarang).

Suarmika, I. G. L., Gede, I. D., \& Suputra, D. (2016). Pengendalian Intern Memoderasi Pengaruh Kapasitas Karangasem Fakultas Ekonomi Dan Bisnis, Magister Akuntansi Unud, Bali, Indonesia Abstrak Pendahuluan Dinamika Perkembangan Sektor Publik Di Indonesia Saat Ini Adalah Semakin Menguatnya Akuntabilitas Tun. 9, 2921-2950,

Sugiyono. (2018). Metode Penelitian Kuantitatif, Kualitatif, Dan RED. Bandung: Alfabeta.

Yendrawati, R. (2013). Pengaruh Sistem Pengendalian Intern Dan Kapasitas Sumber Daya Manusia Terhadap Kualitas Informasi Laporan Keuangan Dengan Faktor Eksternal Sebagai Variabel Moderating. Jurnal Akuntansi E Auditing Indonesia, 17(2), 165-174.

Zulkarnain, W. (2013). Dinamika Kelompok: Latihan Kepemimpinan Pendidikan. Bumi Aksara. 